\title{
Düzenli Egzersiz Yapan 15-17 Yaş Grubu Kız Öğrencilerin Bazı Karaciğer Enzim Aktivitelerinin İncelenmesi
}

\author{
M. Fatih BİLICI ${ }^{1}$ ve Ayça GENÇ² \\ Öz
}

Bu çalışmada, düzenli egzersiz yapan 15-17 yaş grubu kız öğrencilerin bazı karaciğer enzim aktivitelerinin incelenmesi amaçlanmıştır. Çalışmaya herhangi bir sağllk problemi bulunmayan, düzenli olarak spor yapan 17 kız ve fiziksel olarak aktif olmayan $19 \mathrm{k} 1 z$ olmak üzere toplamda 36 ögrenci gönüllü olarak katılmıştır. Sporcu ve sedanter gruplardan 5 cc venöz kan örneği alınmıştır. Alınan kan örnekleri uygun koşullarda 4000 rpm devirde 10 dakika santrifüj edilerek serum örnekleri elde edilmiştir. Serumların analizi otoanalizör cihazı tarafından fotometrik yöntemle yapılmıştır. Veriler SPSS 20.0 istatistik paket programı ile analiz edilmiş ve anlamlılık düzeyi $(p<0.05)$ olarak alınmıştır. İstatistiksel analizlerde Shapiro-Wilk testi ve bağımsız t testleri kullanılmıştır. Çalışmaya katılan sporcu grubun sedanter gruba göre, AST (Asparatat Amino Transferaz), ALT (Alanine Amino Transferase) ve LDH (Laktat Dehidrogenaz) serum düzeylerinin daha yüksek olduğu ve bu farkın istatistiksel olarak anlamlı olduğu tespit edilmiştir ( $\mathrm{p}<0.05)$. Ayrıca her iki grubun GGT (Gama Glutamil Transferaz) serum düzeyleri arasında istatistiksel olarak anlamlı bir fark olmadığı saptanmıştır ( $p>0.05$ ). Sonuç olarak; sporcu grubun sedanter gruba göre AST, ALT ve LDH serum düzeylerinin daha yüksek olduğu saptanmıştır. Karaciğer enzimleri yaş, cinsiyet, vücut kitle indeksi, genetik, yaşam tarzı ve egzersiz gibi birçok faktörden etkilenir. Gruplar arasındaki bu farkın egzersiz ve hareketsiz yaşam biçiminden kaynaklandığı söylenebilir.

Anabtar Kelimeler: Egzersiz, Karaciğer Enzimleri, Kadın

\section{Examination of Liver Enzymes of 15-17 Years Old Female Students Who Performing Regular Exercises}

\begin{abstract}
The prsent work determines some liver enzyme activities of 15-17 years old teenager female students who exercise regularly. A total of 36 female students, 17 of which regularly doing sports and 19 physically inactive, participated in thestudy voluntarily. $5 \mathrm{cc}$ venous blood samples were taken from athlete and sedentaryg roups. Serum samples were obtained by centrifuging blood samples for 10 minutes at $4000 \mathrm{rpm}$ under suitable conditions. The analysisof the serum was done by the autoanalyzer device through the photometric method. The data were analyzed with SPSS 20.0 statistical package program and the significance level was taken as $(\mathrm{p}<0.05)$. Shapiro-Wilk test and independent t-test were used for statistical analysis. It was found that the athletes participated in the study had higher serum levels of AST (Aspartate Amino Transferase), ALT (Alanine Amino Transferase) and LDH (Lactate Dehydrogenase) and this difference was statistically significant $(\mathrm{p}<0.05)$. Besides, there was no statistically significant difference between the GGT (Gama Glutamyl Transferase) serum levels of both groups ( $\mathrm{p}>0.05)$. AST, ALT and LDH serum levels were higher in the athlete group than in sedentary group. Liver enzymes are affected by many factors such as age, sex, body mass index, genetics, lifestyle and exercise. It can be argued that this difference between the groups is caused by exercise and sedentary lifestyle.
\end{abstract}

Key Words: Exercise, Liverenzymes, Female

\section{Atıf İçin / Please Cite As:}

Bilici, M. F. ve Genç, A. (2020). Düzenli egzersiz yapan 15-17 yaş grubu kız öğrencilerin bazı karaciğer enzim aktivitelerinin incelenmesi. Manas Sosyal Araștormalar Dergisi, 9(1), 470-475.

Geliş Tarihi / Received Date: 05.04.2019

Kabul Tarihi / Accepted Date: 09.05.2019

\footnotetext{
${ }^{1}$ Dr. Öğr. Üyesi - Muş Alparslan Üniversitesi Beden Eğitimi ve Spor Yüksekokulu, f.bilici@alparslan.edu.tr ORCID: 0000-0003-1028-0504

2 Dr. Öğr. Üyesi - Bartın ÜniversitesiSpor Bilimleri Fakültesi, aycagenc@bartin.edu.tr ORCID: 0000-0003-2498-7092
} 


\section{Giriş}

Vücudun en büyük ve en önemli metabolik organı olan karaciğer, tek bir organ olmasına rağmen birçok farklı işlev gerçekleştirir. Karaciğer; karbonhidrat, yă̆, protein, hormonlar ve yabancı kimyasalların metabolize edilmesi, vitaminler ve demirin depolanması, kanın filtrasyonu ve depolanması, pıhtılaşma gibi çeşitli görevleri yerine getiren hayati öneme sahip bir organdır (Guyton ve Hall, 2016, s. 797-815). Karaciğerin işlevlerini yerine getirmesine yardımcı olan bazı enzimler vardır ve bu enzimler kan testleri aracıllğı değerlendirilir. Karaciğer fonksiyon testlerinin değerlendirilmesinde başlıca kullanılan enzimler; ALT (alaninaminotransferaz), AST (aspartataminotransferaz), LDH (LaktatDehidrogenaz) ve GGT (gama-glutamyltranspeptidaz)'dir. Sağlıklı bireylerde bu enzimlerin çoğu karaciğerde depolanırken, karaciğerde hasar oluşması durumunda ise bu enzimler kana karışır (Gencer, Çınar ve Comba, 2015, s. 21 26). ALT, LDH, AST gibi enzimlerin karaciğer hasarından ziyade kas hasarından kaynaklı artış gösterdiği ifade edilmektedir (Hammouda vd., 2012, s. 239). Çoğunlukla karaciğerde bulunan ALT enzimi aşırı egzersiz ve kas hasarında artış gösterir (Toklu, 2018, s. 20). Bir diğer enzim olan AST ise kalp, kas dokusu, karaciğerde bulunur ve hareketsiz yaşam tarzının da etkisi ile meydana gelen aşırı yağlanma ve kilo alımı, dengesiz beslenme gibi durumlarda kalp ve iskelet kasında meydana gelen hasara bağlı olarak yükselmeye başlar (Bezci, 2007, s. 23). Dalak, böbrek, pankreas gibi birçok organda bulunan GGT ise karaciğer yağlanması, kalp krizi gibi etmenlerde yükselir (Noyan, 2009, s. 48-55). GGT yüksekliğinin daha çok karaciğer hastalıklarından kaynaklandığ1 söylenebilir (Limdi ve Hyde, 2003, s. 307-312). Karaciğer, kalp, kas gibi dokularda bulunan LDH ise aşırı egzersizde artış gösteren bir enzimdir ve metabolizmanın enerji üretiminde anahtar rol oynar (Petterson, Hindorf ve Persson, 2007, s. 253-259).

Karaciğer enzimleri yaş, hastalık, vücut kitle indeksi, büyüme çağı ve egzersiz gibi çeşitli faktörlere bağlı olarak değisşiklik gösterir. Adolesan dönemde meydana gelen fiziksel ve hormonal değişimler egzersizinde etkisi ile biyokimyasal ve fizyolojik açıdan bu dönemde pik yapabilir. Bu dönem özellikle büyüme çağınıda kapsadığından kişinin fiziksel ve fizyolojik özelliklerinin de etkisi ile karaciğer enzimleri üzerinde dalgalanmaya neden olabilir (Malina, 2007, s. 67-90).

Literatür incelendiğinde uzun süreli ve yüksek şiddette yapılan egzersizin karaciğer enzim aktivitesinde artışa neden olduğu saptanmıştır. Egzersiz ile birlikte homeostasisin korunabilmesi için enzim aktiviteleri değişkenlik gösterir (Hyder, Hasan ve Mohieldein, 2013, s. 280-284). Egzersiz esnasinda hücresel ATP azalır ve bu azalmada hücresel geçirgenliğiarttırır. Artan hücresel geçirgenlik, LDH, AST, ALT gibi iskelet kası kaynaklı bazı enzimlerin serumdaki seviyelerinde hafif artışa neden olur (Öztürk, 2009, s. 30). Literatür incelendiğinde, egzersiz türü ve şiddetine bağl1 olmakla beraber ALT ve AST enzimlerinde artış tespit edilen birçok çalışma bulunmaktadır (Kim vd., 2007, s. 443-447; Petterson vd., 2007, s. 253-259).

Bu çalışmada, düzenli egzersiz yapan 15-17 yaş grubu kız öğrencilerin bazı karaciğer enzim aktivitelerinin incelenmesi amaçlanmıştır.

\section{Yöntem}

\section{Evren - Örneklem}

Çalışmaya herhangi bir sağlık problemi bulunmayan, haftada 5 gün, en az 60 dakika okul takımlarında çeşitli egzersizlere (voleybol, futsal, atletizm) düzenli olarak katılan $17 \mathrm{k}$ z ve fiziksel olarak aktif olmayan 19 kız olmak üzere toplamda 36 öğrenci gönüllü olarak katılmıştır. Gönüllüler çalışma öncesi bilgilendirilmiş ve 70400699-302.14.04-E.1700109787 sayılı ve 11.04.2017 tarihli Atatürk Üniversitesi Spor Bilimleri Fakültesi Etik Kurulu onayı alındıktan sonra çalıssma yapılmışır.

\section{Veri Toplama Araçları}

Çalışmada sporcu ve sedanter gruplardan 5 cc venöz kan örneği alınmıştır. Alınan kan örnekleri uygun koşullarda $4000 \mathrm{rpm}$ devirde 10 dakika santrifüj edilerek serum örnekleri elde edilmiştir. Serumların analizi ARCHITECT Cİ 16200 TM analizöründe fotometrik yöntemle yapılmıştır.

\section{Verilerin Analizi}

Araștırmada elde edilen veriler SPSS 20.0 istatistik paket programı ile analiz edilmiş ve anlamllik düzeyi $(\mathrm{p}<0.05)$ olarak alınmıştır. İstatistiksel analizlerde Shapiro-Wilk testi ve bağımsız $\mathrm{t}$ testleri kullanilmıstır. 


\section{Bulgular}

Tablo 1. Sporcu ve Sedanter Grubun Yaş-Boy-Kilo Tablosu

\begin{tabular}{cccc}
\hline Antropometrik ölçümler & $\boldsymbol{N}$ & Gruplar & $\overline{\mathrm{x}} \pm \boldsymbol{S D}$ \\
\hline Yaş (Y1) & 17 & Sporcu & $15,94 \pm 1,25$ \\
& 19 & Sedanter & $16,52 \pm 0,75$ \\
Boy (cm) & 17 & Sporcu & $1,64 \pm 1,48$ \\
& 19 & Sedanter & $1,63 \pm 1,10$ \\
Kilo (kg) & 17 & Sporcu & $54,70 \pm 1,95$ \\
& 19 & Sedanter & $52,94 \pm 2,95$ \\
\hline
\end{tabular}

Tablo 1 incelendiğinde çalışmaya katılan sporcu grubun yaş ort. $(15,94 \pm 1.25)$, kilo ort. $(54,70 \pm 1.95)$ ve boy ort. (1,64£1.48) iken, sedanter grubun yaş ort. $(16,52 \pm 0.75)$, kilo ort. $(52,94 \pm 2.95)$ ve boy ort. $(1,64 \pm 1.48)$ olduğu tespit edilmiştir.

Tablo 2. Sporcu ve Sedanter Grubun ALT, AST, LDH ve GGT Değerleri

\begin{tabular}{llllll}
\hline \multicolumn{1}{c}{ Parameters } & $\boldsymbol{N}$ & Gruplar & $\overline{\mathrm{x}} \pm S D$ & $t$ & $p$ \\
\hline ALT (Alanin Amino & 17 & Sporcu & $13,76 \pm 4,08$ & \multirow{2}{*}{, $034^{*}$} \\
Transferaz)(U/L) & 19 & Sedanter & $11,32 \pm 2,45$ & & \\
& 17 & Sporcu & $23,06 \pm 5,49$ & 4,57 &, $000^{*}$ \\
AST (Aspartat Transferaz)(U/L) & 19 & Sedanter & $16,58 \pm 2,71$ & & \\
& 17 & Sporcu & $221,35 \pm 40,53$ & 2,07 &, $046^{*}$ \\
LDH (Laktat Dehidrogenaz)(U/L) & 19 & Sedanter & $200,63 \pm 15,56$ & & \\
& 17 & Sporcu & $11,65 \pm 2,34$ &,- 566 &, 575 \\
GGT (Gamma-Glutamyl & 19 & Sedanter & $12,05 \pm 1,93$ & & \\
Transpeptidase)(U/L) & & & &
\end{tabular}

$* \mathrm{p}<0,05$

Tablo 2 incelendiğinde, çalışmaya katılan sporcu grubun sedanter gruba göre AST (Asparatat Amino Transferaz), ALT (Alanine Amino Transferase) ve LDH (LaktatDehidrogenaz) serum düzeylerinin daha yüksek olduğu ve farkın istatistiksel olarak anlamlı olduğu tespit edilmiştir $(p<0,05)$. Ayrıca her iki grubun GGT (Gama GlutamilTransferaz) serum düzeyleri arasında istatistiksel olarak anlamlı bir fark olmadı̆̆1 saptanmıştır ( $\mathrm{p}>0,05)$.

\section{Tartışma, Sonuç ve Öneriler}

Bu çalışmada, 15-17 yaş grubu kızlarda düzenli egzersizin karaciğer enzim aktiviteleri üzerindeki etkisi incelenmiştir. Rosmarın’a göre (1993, s. 252), egzersizin süre ve şiddetinin AST, ALT, LDH değerlerinin artmasında önemli bir etken olduğunu belirtmiştir. 16-27 yaşarası elit kadın sporcularda yapılan çalışmada, LDH düzeyinde bir farklılık görülmez iken AST değerinde anlamlı derecede artış tespit edilmiştir (Fallon, 2007, s. 334-341). Halter gibi kas hasarının yoğun olduğu sporlarda karaciğer fonksiyon parametrelerinde, AST ve ALT'ın yanı sıra LDH, CK ve miyoglobin seviyelerinde derin artışlara yol açtığı saptanmıştır (Pettersson vd., 2008, s. 253-259). Elit kadın ragbi oyuncularında yapılan bir başka çalışmada, kamp dönemini kapsayan yoğun dönemde LDH düzeylerinde anlamlı derecede artış olduğu tespit edilmiştir (Moshiko vd., 2004, s. 186-190). 8 kadın, 16 erkek judocunun katıldığ1 çalışmada, 5 haftalık antrenman sonrası sporcuların ALT ve AST değerlerinde anlamlı artış olduğu tespit edilmiştir (Su, Lin ve Chen, 2001, s. 1154-1158). Maraton koşan kadınlarda yapılan bir çalışmada, maraton koşusundan 24 saat sonra alınan ölçümlerde ALT ve AST değerlerinin anlamlı derecede arttı̆̆1 saptanmıştır (Kratz vd., 2002, s. 856).

Kadın taekwondocuların kamp döneminde ALT, AST ve glikoz düzeylerinde anlamlı artış tespit edilirken, trigliserit ve üre düzeylerinde ise anlamlı farklılık tespit edilmemiştir (Çakmakçı ve Pulur, 2008, s. 39-47). Voleybol ve kick boks yapan kadınlarda LDL düzeyinin anlamlı derecede arttı̆̆1 tespit edilmiştir (Kratz vd., 2002, s. 863; Ji, Yang ve Wei, 2013, s. 712-715).

Uzun mesafe koşucularında yapılan çalışmada, AST, ALT, LDH, CK, GGT düzeylerinde 1 ila 4 saat içerisinde anlamlı artış meydana geldiği saptanmıştır (Güreş, Karul ve Kozac1, 2009, s. 89-95). Yapılan bazı çalışmalarda sporcu gruba kıyasla sedanter kızlarda aerobik egzersiz sonrasında LDL değerlerinde azalış 
meydana geldiği saptanmıştır (Colin vd., 2000, s. 277; Karacan ve Çolakoğlu, 2003, s. 83-88). Her ne kadar egzersize bağlı olarak LDL seviyesinde değişimler meydana gelmesine rağmen literatür incelendiğinde bu değişimlerin genelde akut olarak meydana geldiği gözlemlenmektedir. Bir yıldır düzenli ağırlık egzersizi yapan ve takviye whey proteinin kullanan grubun karaciğer enzimlerinin incelendiği çalışmada, AST, ALT, ALP, GGT değerlerinde anlamlı farklılık tespit edilmiştir (Akkurt, 2019, s. 178-186). Sağlıklı kadın ve erkekler deneklerin biyokimyasal parametrelerinin incelediği çalışmada, ALT, AST, ALP ve GGT değerleri açısından anlamlı fark tespit etmemiştir (Furuncuoğlu vd., 2007, s. 209-211). Aerobik egzersiz GGT değerinde anlamlı farklılığa neden olmaz iken, AST ve ALT değerlerinde anlamı artışa neden olduğu tespit edilmiştir (Pettersson vd., 2008, s. 253).

Çalışmamızda sporcu grubun sedanterlere göre, AST (Asparatat Amino Transferaz), ALT (Alanine Amino Transferase) ve LDH (LaktatDehidrogenaz) serum düzeylerinin daha yüksek ve istatistiksel olarak anlamlı olduğu tespit edilmiştir ( $\mathrm{p}<0,05)$. Ayrıca her iki grubun GGT (Gama Glutamil Transferaz) serum düzeyleri arasında istatistiksel olarak anlamlı bir fark olmadığı saptanmışır ( $\mathrm{p}>0,05)$. Çalışmamızda sporcu grupta egzersizinde etkisiyle AST, ALT ve LDH düzeylerindeki artış literatür ile paralellik göstermektedir.

Sonuç olarak; sporcu grubun sedanter gruba göre AST, ALT ve LDH serum düzeylerinin daha yüksek olduğu saptanmıştır. Karaciğer enzimleri yaş, cinsiyet, vücut kitle indeksi, genetik, yaşam tarzı ve egzersiz gibi birçok faktörden etkilenir. Gruplar arasındaki bu farkın egzersiz ve hareketsiz yaşam biçiminden kaynaklandığ1 söylenebilir.

\section{Kaynakça}

Akkur, G. (2019). Düzenli ağırllk egzersizi yapan bireylerde izole hidrolize whey proteini kullanımının tiroid hormonları, karaciğer ve böbrek fonksiyon testleri üzerine etkisi. Ankara Med J,1, 178-186.

Bezci, Ş. (2007). Elit taekwondocularda antrenman öncesi ve sonrast baž hematolojik ve biyokimyasal parametrelerin incelenmesi (Yüksek lisans tezi). Selçuk Üniversitesi, Sağlık Bilimleri Enstitüsü, Konya.

Colin, A. G., William, F. M. ve Nevill, A. (2000). Training effects of accumulated daily stairclimbing exercise in previously sedentary young women. Preventive Medicine,30, 277-281.

Çakmakçı, E. ve Pulur, A. (2008). Milli takım kamp döneminin bayan taekwondocularda bazı biyokimyasal parametreler üzerine etkisi. S.Ü. Bes Bilim Dergisi, 10, 39-47.

Fallon, K.E. (2008). The clinical utility of screening of biochemical parameters in elite athletes. BrJ Sports Med, 42(5), 334-341.

Furuncuoğlu, Y., Karaca, E. ve Aras, S. (2007). Metabolic, biochemical and psychiatric alterations in healthy subjects during ramadan. Pakistan Journal of Nutrition, 6(3), 209-211.

Gencer, Y.G., Çınar, A. ve Comba. B. (2015). Stresin ratlarda bazı karaciğger enzimleri (AST, ALT, ALP) üzerine etkilerinin araşttrilması. Atatürk Üniversitesi Veteriner Bilimleri Dergisi, 10(1), 21-26.

Güreş, A., Karul, A. ve Kozacı, D. (2009). Mesafe koşucularında submaksimal egzersizin kan biyokimyasına etkisi. Spor Hekimliği Dergisi, 44, 89-95.

Hall, J. E. (2016). Guyton ve Hall tıbbi fišoloji (13. Baskı). Ankara: Güneş Tip Kitabevleri.

Hammouda, O., Chtourou, H., Chaouachi, A., Chahed, H., Ferchichi, S., Kallel, C. ve Souissi, N. (2012). Effect of short-term maximal exercise on biochemical markers of muscle damage, total antioxidant status, and homocysteine levels in football players. Asian Journal of Sports Medicine, 3(4), 239.

Hyder, M. A., Hasan, M. ve Mohieldein, A. H. (2013). Comparative levels of ALT, AST, ALP and GGT in liver associated diseases. European Journal of Experimental Biology, 3(2), 280-284.

Ji-Qing, X., Yang, Z. ve Wei, F. (2013).The effect of pre-competition training on biochemical indices and immune function of volleyball players. Int J Clin Exp Med, 6(8), 712-715.

Karacan, S. ve Çolakoğlu, F. F. (2003). Sedanter orta yaş bayanlar ile genç bayanlarda aerobik egzersizin vücut kompozisyonu ve kan lipidlerine etkisi. Spormetre/Beden Egitimi ve Spor Bilimleri Dergisi, 1(2),83-88.

Kim, H. J., Lee, Y. H. ve Kim, C. K. (2007). Biomarkers of muscle and cartilage damage and inflammation during a $200 \mathrm{~km}$ run. European Journal of Applied Physiology, 99(4), 443-447.

Kratz, A., Lewandrowski, K. B. ve Siegel, A. J. (2002). Effect of marathon running on hematologic and biochemical laboratory parameters, including cardiac markers. American Society for Clinical Pathology, 118, 856-863.

Limdi, J. K. ve Hyde, G. M. (2003). Evaluation of abnormal liver function tests. Postgrad Med J, 79, 307-312.

Malina, R. (2007).Physical fitness of children and adolescents in the United States: Status and secular change. Pediatric Fitness, 50, 67-90.

Mashiko, T., Umeda, T. ve Nakaji, S. (2004). Effects of exercise on the physical condition ofcollege rugby players during summer training camp. BrJ Sports Med, 38, 186-190.

Noyan, T. (2009). Serum Gama Glutamil Transferaz: Son Elde Edilen Bulgular ve Çeşitli Hastalıkların Fizyopatolojisindeki Önemi. Van Tip Dergisi, 16(1), 48-55.

Öztürk, Ç. (2009). Sporcularda ve sedanter bireylerde akut egzersiz öncesi gliserol takviyesinin baž biyokimyasal parametreler ile laktat ve aerobik, güc üzerine etkileri (Yüksek Lisans Tezi). Selçuk Üniversitesi, Sağllk Bilimleri Enstitüsü, Konya. 
Pettersson, J., Hindorf, U. ve Persson, P. (2008). Muscular exercise can cause highly pathological liver function tests in healthy men. British Journal of Clinical Pharmacology, 65(2), 253-259.

Rosmarın, M., Beard, M. J. ve Robbıns, S. W. (1993). Serum enzyme activities in individuals with different levels of physical fitness. Journal of Sports Medicine And Physical Fitness, 33(3), 252-257.

$\mathrm{Su}, \mathrm{Y}$., Lin, C. ve Chen, K. (2001). Effects of huangqi jianzhong tang on hematological and biochemical parameters in judo athletes. Acta Pharmacol Sin, 22, 1154-1158.

Toklu, A. (2018). Amatör futbolcularda maç sezonu süresince sezon içi antrenman programmnn kas hasar biyokimyasal parametreler üzerine etkisi (Yüksek lisans tezi). Balıkesir Üniversitesi, Sağlık Bilimleri Enstitüsü, Balıkesir.

\section{EXTENDED ABSTRACT}

Despite being a single organ, liver, which is the largest and most important metabolic organ of the body, performs a number of different functions. The liver is a vital organ that performs a variety of tasks such as metabolizing carbohydrates, fats, proteins, hormones and foreign chemicals, storing vitamins, iron and performing the filtration, storage and coagulation of blood (Guyton, \& Hall, 2016, p. 797-815). There are certain enzymes that help the liver perform its functions and these enzymes are analyzed through blood tests. The primary enzymes checked in the evaluation of liver function tests are ALT (Alanine Amino Transferase), AST (Aspartate Amino Transferase), LDH (Lactate Dehydrogenase) and GGT (Gamma-Glutamyl Transpeptidase). In healthy individuals, most of these enzymes are stored in the liver, in case of damage to the liver, however, these enzymes are mixed into the blood (Gencer, Çinar, \& Comba, 2015, p. 21-26). It is stated that enzymes such as ALT, LDH and AST increase due to muscle damage rather than liver damage (Hammouda vd., 2012, p. 239). ALT enzyme found mostly in the liver shows increased exercise and muscle damage (Toklu, 2018, p.20). Another enzyme, AST, is found in the heart, muscle tissue and liver, and starts to increase due to damage to the heart and skeletal muscles in situations such as excessive fattening, weight gain and unbalanced nutrition caused by the sedentary lifestyle (Bezci, 2007, p. 23). GGT, which is found in many organs such as spleen, kidney, pancreas, increase swith factors such as liver fattening and heart attack (Noyan, 2009, p. 48-55). It can be argued that high GGT rate is mostly caused by liver diseases (Limdi, \& Hyde, 2003, p. 307-312). LDH, which is found in tissues such as liver, heart and muscle, is an enzyme that increases with excessive exercise and plays a key role in the energy production of the metabolism (Petterson, Hindorf, \& Persson, 2007, p. 253 259). Liver enzymes depending on various factors such as age, disease, body mass index, growth age and exercise. Physical and hormonal changes occurring during adolescence can be peaked in this period in terms of biochemical and physiological effects. This period may involve fluctuations in liver enzymes due to the physical and physiological characteristics of the person, especially as it covers the growing age (Malina, 2007, p. 67-90). Liver enzymes may vary depending on various factors such as age, disease, body mass index, adolescence and exercise. Physical and hormonal changes that occur in adolescence may culminate in terms of biochemical and physiological aspects with the effect of exercise. Since this period includes especially the growth period as well, it may cause fluctuation on the liver enzymes due to the physical and physiological characteristics of the person. When the literature is examined, it is determined that long-term and high-intensity exercise leads to an increase in liver enzyme activity. Enzyme activities vary in order to maintain homeostasis together with exercise (Hyder, Hasan, \& Mohieldein, 2013, p. 280284) Cellular ATP decreases during exercise causing an increase in cellular permeability. Increased cellular permeability causes a slight increase in serum levels of some skeletal muscle-induced enzymes, such as LDH, AST, and ALT (Öztürk, 2009, p.30). There are several studies in the literature that found an increase in the ALT and AST enzymes depending on the type and severity of the exercise (Kim et al, 2007, p. 443-447; Petterson et al, 2007, p. 253-259). In our study, it was aimed to determine some liver enzyme levels in serum samples of 15-17 years old teenager female students who performing regular exercise. A total of 36 female students, 17 of which regularly do sports and 19 physically inactive, participated in the study voluntarily. $5 \mathrm{cc}$ venous blood samples were taken from athlete and sedentary groups. The blood samples collected were centrifuged at $4000 \mathrm{rpm}$ for 10 minutes in convenient conditions and serum samples were obtained. Serum analysis was performed by autoanalyzer device through the photometric method.

Data were analyzed with SPSS 20.0 statistical package program and the significance level was taken as $(\mathrm{p}<0.05)$. Shapiro-Wilk test and independent $\mathrm{t}$-test were used for statistical analysis. It was found that the athletes participated in the study had higher serum levels of AST (Aspartate Amino Transferase), ALT (Alanine Amino Transferase) and LDH (Lactate Dehydrogenase) than the sedentary group and that this 
difference was statistically significant $(\mathrm{p}<0.05)$. Besides, there was no statistically significant difference between the GGT (Gama Glutamyl Transferase) serum levels of the two groups ( $\mathrm{p}>0.05)$.

In conclusion, AST, ALT and LDH serum levels were found to be higher in the athlete group when compared to the sedentary group. Liver enzymes are affected by many factors such as age, sex, body massindex, genetics, lifestyle and exercise. It can be argued that this difference between the groups stems from exercise and sedentary lifestyle. 